JURNAL NOMOSLECA

Volume 3, Nomor 2, Oktober 2017

\title{
Perilaku Komunikasi Antarbudaya Pasutri Kawin Campur (Perspektif Drama Turgi)
}

\author{
Dodot Sapto Adi \\ Program Studi Ilmu Komunikasi, FISIP, Universitas Merdeka Malang \\ dodot.sapto@unmer.ac.id
}

\begin{abstract}
Research conducted in the city of Malang, East Java in 2017, has been able to describe the behavior, and also reveal the strategy of constructing the behavior of intercultural communication in order to maintain household harmony. Similarly, regarding personal communication model, by emphasizing the factor of openness to be the main in building the values that are favored or referenced, and with that foundation also other factors in personal relationships can easily follow. The method of qualitative naturalistic analysis is interactive, becoming the basic reference for obtaining relevant data. While the use of phenomenology approach, it is useful to explore the personal experience of informants in married life, so it is easy to formulate together with informants about normative concepts that are commonly applied in pragmatic problem solving. The results of this study can find the importance of improving the behavior of intercultural communication between married couples, in order to achieve a harmony relationship through the process of understanding to position his partner and his nearest social environment. The basic principles of family communication are important in addressing common problems, and intimate communication should always be created at every opportunity. Both of these factors can run effectively, if each marriage marriage partner provides an opportunity for her partner to present her role.
\end{abstract}

Keywords: married couples, intercultural communication behavior, family turgi drama

\begin{abstract}
Abstrak
Penelitian dilaksanakan di kota Malang Jawa Timur tahun 2017, mendeskripsikan perilaku komunikasi antarbudaya, dan strategi mengkonstruksinya guna mempertahankan keharmonisan berumah tangga. Demikian pula mengenai model komunikasi personal, dengan mengedepankan faktor keterbukaan menjadi yang utama dalam membangun nilai-nilai yang dipreferensikan, dan faktor lain dalam hubungan personal dapat dengan mudah mengikutinya. Metode analisis kualitatif naturalistik bersifat interaktif, menjadi acuan dasar untuk memperoleh data yang relevan. Sedangkan penggunaan pendekatan fenomenologi, menggali pengalaman pribadi informan dalam kehidupan berumah tangga, sehingga mudah merumuskan bersama dengan informan mengenai konsep-konsep normatif yang biasa diterapkan dalam penyelesaian setiap masalah secara pragmatis. Hasil penelitian memperbaiki perilaku komunikasi antarbudaya diantara pasutri kawin campur, agar tercapai hubungan harmoni melalui memahami untuk memposisikan pasangannya maupun lingkungan sosial terdekatnya. Prinsip dasar komunikasi keluarga menjadi penting dalam mengatasi problematika umum, dan komunikasi intim harus selalu diciptakan. Kedua faktor tersebut berjalan efektif, jika pasutri memberikan kesempatan bagi pasangannya untuk mempresentasikan perannya.
\end{abstract}

Kata kunci: pasutri kawin campur, perilaku komunikasi antarbudaya, drama turgi keluarga 


\section{PENDAHULUAN}

Berabad-abad Indonesia memiliki faham ragam kebudayaan (multi kultural), karena negara ini merupakan wilayah yang memiliki masyarakat majemuk dengan suku bangsa sebagai salah satu unsur kemajemukan, dan tersebar mendiami seluruh kepulauan nusantara. Di Indonesia terdapat sekitar 380 suku bangsa dan kurang lebih 200 bahasa daerah. Keseluruhan kelompok suku bangsa ini bercorak Bhineka Tunggal Ika, yang merupakan suatu kesatuan utuh yang tidak dapat dicerai-beraikan, masing-masing suku bangsa terwujud sebagai satuan masyarakat dan kebudayaan yang berdiri sendiri dan disatukan oleh kekuatan nasional suatu bangsa. Faktor-faktor yang menyebabkannya antara lain karena wilayah Indonesia terdiri dari beribu-ribu pulau, dan penduduk Indonesia bermacammacam keturunan. Indonesia sebagai negara yang terdiri dari bermacam-macam suku bangsa (multietnik), dengan derajat keberagaman yang tinggi dan mempunyai peluang yang besar dalam perkawinan yang berbeda budaya atau suku, satu sisi fakta ini merupakan kekayaan budaya dan sisi lainnya sebagai perbedaan yang dapat berpotensi munculnya konflik.

Sangat bisa dipahami keberadaan budaya yang berkembang di lingkungan sosial sebagai kesatuan yang memiliki norma atau hukum. Berdasarkan perspektif sistem sosial bahkan mampu mempengaruhi perubahan diri seseorang berupa sikap perilaku, dan simbol-simbol sebagai identitas diri maupun kelompok, dan biasanya dikomunikasikan dari satu generasi ke generasi selanjutnya. Adat mendapatkan kesahihannya yang terpelihara sejak awal munculnya masyarakat, sehingga selalu dapat dikembangkan berdasarkan tingkat kebutuhan untuk memperkuat posisi pranata sosial yang ada. Kondisi ini senmakin diperjelas dengan kemajuan di bidang teknologi komunikasi membawa pengaruh besar terhadap kontak budaya antarsuku. Kota-kota besar telah menjadi tempat berkumpulnya orang dari berbagai suku, dengan begitu penyebarannya menjadi sangat cepat. Perjumpaan dengan lawan jenis yang berbeda suku telah menjadi hal yang tak terhindari. Demikian halnya dengan hubungan asmara, telah mempengaruhi orang-orang dari beragam budaya atau suku, dan pada akhirnya menumbuhkan tekad baru untuk menuju pada jenjang yang lebih tinggi, yaitu membangun mahligai rumah tangga.

Kerap jalinan cinta yang terbentuk itu kemudian pudar, berbagai faktor menjadi penyebab terjadinya kegagalan menuju jenjang rumah tangga bahagia dan abadi. Tantangan yang pertama harus dihadapi adalah terdapatnya perbedaan suku dan kepercayaan, dan biasanya menimbulkan tindakan melawan tradisi dengan cara kawin lari atau melakukan pernikahan tanpa ijin orang tua. Pernikahan beda budaya merupakan suatu keadaan yang diperoleh dari hasil keputusan bersama untuk melakukan pernikahan antarbudaya, terdapat penyatuan pola pikir dan cara hidup yang berbeda menjadi terintegrasi, bertujuan dalam meraih harapan bersama melalui proses membangun institusi rumah tangga. Peristiwa ini membawa masyarakat saling terikat dengan suku-suku maupun etnis yang berbeda. Kesadaran untuk menerima serta diterima keberadaannya oleh pihak lain, selalu menjadi harapan bersama untuk dapat diperjuangkan melalui berbagai cara yang sudah dituntun norma sosial budaya yang berlaku. Sedapat mungkin juga 
berusaha untuk meminimalisasi terjadinya resistensi melalui proses adaptasi, sehingga kondisi yang tercipta menjadi daya dukung untuk memperoleh kebahagiaan sesegera mungkin.

Problematika pasutri hasil
perkawinan antar budaya selalu
dihadapkan pada perbedaan adat, budaya maupun kebiasaan yang harus dilalui. Seringkali adaptasi dalam perkawinan antarsuku atau budaya sukar diatasi. Oleh karena itu, adanya perbedaan kebiasaankebiasaan adat dan budaya, maupun lainnya harus dapat diatasi bersama. Disitulah sebenarnya manusia akan menjalani berbagai fase-fase dalam kehidupannya. Perkawinan tidak dilembagakan sekedar untuk memuaskan keinginan-keinginan alami atau nafsu yang bergejolak. Tujuannya jauh lebih dalam daripada realitas yang bersifat fisik itu. Perkawinan lebih daripada sekedar sarana untuk mendapatkan kepuasan seksual secara sah, tetapi membangun dengan sadar sebuah lembaga amat penting yang mengamankan hak-hak pria, wanita dan anak-anak sembari memuaskan kebutuhankebutuhan fisik, emosi, dan intelektual para anggota keluarga. Dari penjelasan tentang perkawinan tersebut, menunjukkan adanya satu tujuan untuk membentuk keluarga (rumah tangga) yang bahagia serta diliputi rasa tentram dengan dilandasi rasa cinta. Tujuan perkawinan untuk mewujudkan mahligai rumah tangga yang selalu dihiasi dengan keluhuran nilai-nilai sosial.

Kondisi sosial yang teruraikan tersebut, menunjukkan adanya berbagai motif tindakan individu dalam proses membentuk rumah tangga meskipun harus dilakukannya dengan menerobos batasbatas budayanya sendiri. Hal ini sebagaimana yang terjadi pada kota-kota besar di seluruh Indonesia, juga mengalami pengalaman serupa, apalagi kehadiran seseorang yang melakukan perjalanan hidup lintas budaya selalu memiliki alasan yang rasional dan dapat diterima. Termasuk perubahan cara pandang masyarakat kota Malang, yaitu yang memiliki keragaman budaya sejak awal jauh sebelum masa pemerintahan kolonial. Kota terbesar kedua di Jawa Timur ini merupakan tempat yang banyak dihuni warga pendatang, dengan berbagai macam alasan yang sangat umum untuk bekerja dan meneruskan pendidikan, meskipun pada kenyataannya sampai dengan melakukan pernikahan serta berdomisili di kota Malang. Kondisi ini membuktikan, bahwa masih banyak sejarah kota yang belum terungkap secara jernih serta masih berpeluang besar untuk diungkapkan. Bahkan dalam catatan perjalanan pemerintahan kolonial Belanda, telah mengukir kota Malang sebagai primadona sejak tahun 1870 melalui situasi sosial yang disebut dengan Revolusi Gula, yaitu berisikan kebebasan masyarakat dunia untuk menanamkan investasinya melalui sewa lahan sampai dengan 75 tahun.

Saat itu sebagian besar orang Belanda berbondong-bondong datang ke Malang untuk menanam kopi, dalam rangka memenuhi kebutuhan ekspor ke Eropa yang bernilai sangat tinggi. Kota Malang dianggap daerah yang subur, mempunyai udara sejuk dan mempunyai akses jalan utama ke pelabuhan Surabaya. Pada tahun yang sama, Wali Kota Malang didukung 40.000 orang penduduk (33.500 pribumi, 2.500 Belanda, dan 4.000 China, dan Arab) sangat berani untuk mengajukan beberapa hal yang kontroversial. Seperti melakukan reformasi pemerintahan (bestuurs-hervormings-ordonnantic, 1922) dari sistem desentralisasi menjadi 
dekonsentrasi yang memperoleh wewenang mengatur daerah lebih besar dan kotapraja (gemeente) diganti dengan staadsgemeente. Pertama kali terlahir sebagai kota dengan luasnya 15,03 kilometer persegi dengan jumlah penduduk 40 ribu orang, sekarang menjadi 110 kilometer persegi dengan jumlah 820.000 orang. Dari sinilah sebenarnya sudah terlahir konsep globalisasi di bidang ekonomi politik, dan selanjutnya berdampak sangat signifikan terhadap pola pikir hubungan antarbudaya yang diwariskan secara lintas generasi.

Sebagaimana studi pada daerah yang berbeda, telah dilakukan oleh (Hutajulu, 2015) juga menegaskan, bahwa sikap yang positif meliputi rasa saling menghargai, saling menjaga kehormatan selama dinaungi hubungan pernikahan, dan membuang jauh-jauh prasangka yang dinilai buruk. Semakin mendalami proses interaksi pasutri kawin campur yang jelasjelas berbeda budaya, pada dasarnya sudah ada tindakan bersifat komunikatif dengan mengedepankan adanya proses keterbukaan, fleksibilitas dalam memahami setiap tindakan, mengembangkan toleransi atas nilai-nilai yang dianut, dan selalu memberikan dukungan moral bagi pasangannya. Semua dilakukan dengan harapan selalu tumbuhnya saling bisa menerima keadaan, dengan cara mengembangkan perasaan yang positif melalui penekanan seminimal mungkin saling menjauhi yang berdampak pada jarak personal. Namun dalam perjalanan selanjutnya, perkawinan tidaklah selalu berjalan mulus. Banyak permasalahan atau konflik yang muncul dan harapan yang tidak realistis atau berkontribusi pada ketidak puasan dan perceraian.
Berbagai media telah banyak mempublikasikan kerawanan sosial akibat dari perjalanan rumah tangga antarbudaya. Sejak tahun 2015 sampai dengan sekarang (3 tahun), telah tercatat sebanyak 1052 gugatan perceraian dan 73 perkara perceraian yang telah diputuskan. Berbagai upaya juga dengan penuh kesadaran telah dilakukan pasangan suami istri (pasutri) antarbudaya, baik mental maupun perilaku untuk menguasai keadaan terburuk, mentoleransi setiap tindakan maupun pendapat pasangannya, mengurangi atau meminimalisasikan situasi atau permasalahan yang sedang dihadapi untuk memperoleh rasa aman dalam diri masingmasing. Namun pada kenyataannya dalam menyelesaikan setiap permasalahannya, individu mempunyai cara pandang tersendiri, juga disesuaikan dengan perkembangan kepribadiannya, begitu pula dilihat dari sejauh mana tingkat stess pada saat menghadapi masalah serta upaya menemukan solusinya. Namun melalui berbagai studi yang telah dilakukan, bahwa pada kondisi terburuk sekalipun sebenarnya pasutri mampu bertahan dalam jangka panjang, dengan mengedepankan asas saling menghargai melalui pemahaman yang mendalam mengenai perilaku komunikasi pasutri antarbudaya yang mengunggulkan nilai-nilai diri pasangannya, agar mampu mempererat jalinan hubungan dalam rumah tangga yang dibina serta diharapkan untuk dapat memberikan rasa bahagia bersama.

Demikian pula dengan hasil studi yang dilakukan oleh (Abas, Laisa, dan Talani, 2014) menguatkan, bahwa masalah-masalah yang sering muncul dan berpotensi konflik cenderung berkaitan dengan problematika di luar diri pasutri antarbudaya. Untuk mengatasinya cukup dengan mengembangkan kebersamaan 
dengan memupuk rasa saling percaya, menghormati, menerima, menoleransi adat, dan belajar bahasa etnis. Faktor-faktor inilah dalam situasi interpersonal sering mencuat serta menjadi perbincangan utama, bahkan dapat berpengaruh pada jalinan hubungan yang sudah ada, demikian pula akan terus menjadi alasan terjadinya konflik diantara pasutri. Memperhatikan semua problematika yang menghantui terjadinya konflik pasutri kawin campur tersebut, ternyata dapat diatasi dengan memelihara baik komunikasi dua arah secara berkesinambungan, sehingga dapat meningkatkan peran masing-masing dalam struktur keluarga.

Penegasan mengenai pentingnya tindakan komunikatif, dengan menonjolkan nilai-nilai yang dianggapnya penting untuk mempererat hubungan pasutri kawin campur, menjadi faktor penentu bagi kelangsungan keluarga yang di dalamnya dihantui konflik atas dasar perbedaan budaya. Hal ini sejalan dengan diskusi hasil studi yang telah dilakukan oleh (Oktafiani, Ramli, dan Kurniawati, 2014), bahwa saat menghadapi konflik pasutri biasanya berusaha bersikap kompetitif, dengan mempertahankan argumentasi masing-masing. Setelah itu pasutri yang dihadapkan dalam situasi memasuki tahapan anti klimaks yang ditunjukkan dengan tindakan berunding, untuk saling menggali penyebab konflik yang ditunjukkan dengan sikap penghindaran. Akhirnya semua mengubah gagasan komunikasi yang dianggapnya mampu meredakan ketegangan. Dari berbagai studi mengenai pasangan suami istri (pasutri) kawin campur, disinyalir masih menyimpan keunikan tersendiri, baik pada tingkatan personal maupun perkembangan sosial yang cukup rumit prosesnya.

Perilaku komunikasi antarbudaya pada saat sekarang ini, telah memasuki atmosfer perdebatan paling menentukan. Terlebih lagi bila dikaitkan dengan keberadaan pendatang dari wilayah lain, baik yang masih berstatus sebagai warga negara asing (WNA) maupun perpindahan warga antardaerah (WNI) dengan berbagai alasannya yang cukup mendasar, ternyata membawa persoalan baru bagi masyarakat lokal dalam bentuk positif dan negatif. Situasi ini semakin membawa kerumitan tersendiri, apabila dihadapkan dengan status perkawinannya. Berdasarkan uraian tersebut, maka dapat dirumuskan urgensi penelitian mengenai perilaku komunikasi pasutri antarbudaya dalam mengembangkan peranannya di dalam lingkungan keluarga maupun sosial. Melalui penelitian yang mendalam terhadap fenomena yang berkembang selama ini, justru dapat diharapkan menemukan pendekatan yang terintegratif yang menjamin proses pengkayaan perspektif sosial budaya, sehingga semakin terbuka pemahaman mengenai upaya mengkonstruksi perilaku komunikasi pasutri dengan meletakkan prinsip kehidupan rumah tangga beda budaya, yaitu sebagai bagian dari panggung kehidupan yang harus dijalani secara bersama-sama.

\section{METODE PENELITIAN}

Penelitian ini bersandar pada paradigma subjektif, melalui pendekatan observasi aktif serta menggunakan analisis kualitatif, sehingga proses penggalian informasi menjadi tumpuan utama untuk menuju objektivitas penelitian (Sugiyono, 2015). Kegiatan penelitian yang bersifat 
interaktif ini, memudahkan proses untuk mendeskripsikan fakta yang utuh. Sekaligus juga dapat melakukan analisis data yang ditopang wawancara mendalam sesuai dengan fokusnya mengenai pandangan dalam ikatan kawin campur pada pasutri, faktor-faktor dalam konflik yang sering terjadi, perilaku komunikasi di dalam tata cara mengatasi konflik antarbudaya, sampai dengan penerapan nilai-nilai yang sering dimunculkan (assertive preference values) dalam proses komunikasi sebagai adat berumah tangga oleh pasutri kawin campur. Dengan memanfaatkan studi pendahuluan yang cukup waktu, maka kemudahan dapat diperoleh dalam rangka menghimpun data yang dibutuhkan secara tepat, dan memiliki tingkat validitas tinggi yang dapat dipertanggungjawabkan.

Melalui penerapan teknik purposif dapat diperoleh 9 (sembilan) pasutri yang secara aktif diteliti, meskipun pada saat wawancara hanya sebagian pasutri utuh dalam waktu bersamaan yang bisa berdiskusi aktif, dan sebagian lagi hanya bisa melakukan wawancara secara tunggal. Wawancara lebih banyak dilakukan di rumah, mengingat kondisi informan memiliki kesibukan tersendiri ketika ada di luar rumah. Keuntungan yang diperoleh peneliti, adalah berusaha menjadi teman baik dengan saling menghormati posisi masing-masing. Intensitas untuk bertemu dengan informan dapat dicapai sampai dengan 3 kali, dengan durasi yang cukup panjang untuk memperhatikan perilaku komunikasinya. Semua data yang dibutuhkan sudah mencukupi untuk dilakukan analisis secara interaktif, mengingat pada dasarnya antara posisi informan dan peneliti sudah melakukan hubungan dekat secara kekeluargaan. Maksud serta tujuan penelitian telah dipahami bersama, sehingga keterbukaan dan keutuhan informasi yang dibutuhkan tidak mengalami kendala yang berarti. Meskipun demikian identitas informan tetap terjaga dengan baik sesuai permintaan (Bungin, 2011).

Disamping menggunakan pendekatan subjektif naturalistik, maka prosesnya dilandasi metode fenomenologi berbasis pada pemikiran Edmund Husserl (18591938), agar peneliti mampu mengungkap lebih mendalam komunikasi pasutri pada keluarga antarbudaya, melalui metode ini akan semakin terbuka untuk mereduksi kesadaran informan dalam memahami bagaimana fenomena komunikasi pasutri mengonstruksi nilai-nilai komunikasi keluarga tersebut. Pemikiran fenomenologi berfokus pada pengalaman personal individu. Realitas adalah bukan suatu yang sederhana yang untuk pemahamannya tidaklah cukup hanya berbekal pengamatan sepintas. Realitas mengenai dunia fenomena dan noumena seperti yang disebutkan Immanuel Kant. Dunia fenomena menurut Mulyana (2001: 19), sehingga masalah yang berkembang lebih bersifat intersubjektif, bahkan lebih mengarah pada pengalaman individu yang penuh dengan konstruksi makna.

Dunia fenomena adalah dunia informasi diperoleh dari pancaindra manusia berperan aktif dalam membangun dan menafsirkan sensasi-sensasi inderanya sebagai sebuah pengalaman sadar, dan dalam perkawinan antarbudaya tersebut terjadi sebuah bentuk kesadaran yang menghasilkan pemaknaan intersubjektif. Hal ini sesuai dengan konsep utama dalam fenomenologi, dan merupakan isi penting yang muncul dari pengalaman kesadaran manusia. Pemahaman tersebut sejalan dengan apa yang menjadi telaah 
fenomenologi yang diuraikan Littlejohn (2005: 38) sebagai people actively interpret their experience and come to understand the world by personal experience with it. Di sisi lain, Kuswarno (2009:25) menjelaskan dengan tegas bahwa sesungguhnya pengalaman sadar memang menjadi titik awal dalam pembahasan fenomenologi, untuk sebuah kesadaran dari pengalaman (awareness of experience) sebagai memberikan sudut pandang pengalaman orang pertama.

\section{HASIL PENELITIAN DAN PEMBAHASAN}

\section{Hasil Penelitian}

\section{a. Kota Malang}

Dengan julukan sebagai kota terbesar kedua di Jawa Timur setelah kota Surabaya, telah memposisikan kota Malang sebagai wilayah yang sangat strategis dalam percepatan pembangunan. Kota yang memiliki lima daerah kecamatan yaitu Kedungkandang, Sukun, Blimbing, Lowokwaru dan Klojen serta terdiri atas 57 kelurahan (BPS Kota Malang, 2017). Kota tersebut dihuni oleh kurang lebih 857.891 jiwa dan memiliki beberapa julukan seperti Malang Kota Bunga karena pada saat itu memiliki pemandangan bunga-bunga dan pohonpohon yang memberi kesan asri, Kota pendidikan sebab, merupakan salah satu tujuan bagi mahasiswa dan pelajar dari berbagai wilayah tanah air, yaitu untuk melanjutkan studi dalam berbagai tingkatan pendidikan. Secara geografis berada pada ketinggian 444 meter dari permukaan air laut, menjadikan kota Malang memiliki ketinggian yang cukup untuk menampung kesejukan udara pda luas wilayah mencapai $252,10 \mathrm{~km}$ persegi.
Kota Malang merupakan daerah otonomi yang berdiri sejak tahun 1914, dan dalam usianya ke 103 tahun menyimpan kenangan yang sangat kuat dengan keberadaan warga asing. Hal ini mengingat Kota Malang sangat lama menjadi pusat masa pemerintahan kolonial sampai dengan republik, sebagaimana dapat diamati melalui peninggalan gedunggedung tua yang sampai sekarang masih terpelihara serta menjadi aset pemerintah. Kota yang terkenal kesejukannya ini, masih mempertahankan keberadaan ruang publik kuno yang dibangun sejak pemerintahan belanda. Seperti halnya ruang terbuka berupa taman hutan kota serta taman rekreasi kota, menjadi incaran warga Kota Malang untuk melakukan berbagai macam kegiatan. Pasar Besar Kota Malang masih dipertahankan eksistensinya menjadi pusat transaksi ekonomi tradisional, dan telah dikembangkan menjadi salah satu simbol keunggulan sosial ekonomi.

Seperti kota-kota besar lainnya, saat ini investasi banyak dikembangkan untuk membangun hotel-hotel baru, untuk memfasilitasi terpenuhinya bagi wisatawan domestik maupun mancanegara (Hudiyanto, 2011). Kota Malang juga mengikuti akselerasi pembangunan sebagai kota terbesar kedua di Jawa Timur, yaitu dengan berorientasi pada pengembangan sektor pariwisata domestik yang menyuguhkan keindahan alam. Selain itu kota Malang telah meraih berbagai prestasi dalam pembangunan untuk bidang Pendidikan, Kepariwisataan, dan Industi. Khususnya untuk bidang pembangunan yang terakhir ini, memiliki daya tarik tersendiri untuk pengembangan potensi ekonomi dan perdagangan, sehingga mampu menarik minat berbisnis pada 
tingkatan regional sampai dengan internasional. Dapat dipastikan, bahwa perkawinan antaretnis dan keturunan sesama WNI memiliki urgensi tersendiri, disamping juga yang melibatkan WNA dalam kerangka relasi antarbudaya.

\section{b. Informan Penelitian}

Upaya mendekati informan dilakukan melalui pengamatan terlebih dahulu, dengan cara mencari penghubung melalui komunitas maupun lingkungan keluarga serta pergaulan, agar tidak terjadi sikap penolakan lebih dini sebagai akibat salah pemahaman. Tahapan menjadi menjalin hubungan dan membangun persahabatan menjadi kunci utama dalam menggali data dari informan. Segala sesuatunya dilaksanakan melalui proses kekeluargaan, dan bahkan pertanyaanpertanyaan yang sangat sensitif tidak diajukan secara tegas, dan hanya menggunakan bahasa kiasan yang mudah dipahami informan. Penelitian lebih mementingkan untuk mengungkap seputar kehidupan informan sebelum bertemu pasangan, tahap awal perkenalan hingga saat memutuskan untuk menikah sampai dengan keinginan memiliki keturunan. Apabila tahapan ini sudah terlampaui, maka secara otomatis kedekatan dengan terbentuk dengan sendirinya, sehingga tidak ada kecanggungan mengajukan pertanyaan pada faktor-faktor yang bersifat pribadi serta sensitif.

Terdapat 9 (sembilan) informan yang terbagi ke dalam 3 (tiga) kategori untuk diteliti. Kategorisasi diperlukan agar konsistensi pada fokus penelitian tetap terjaga untuk mengetahui fakta-fakta tentang interaksi yang dilakukan dilihat dari keberagaman budaya. Kategori pertama sebanyak 2 (dua), termasuk bagi pasutri yang menikah campur dengan batasan pada pasangan antara WNI (etnis Indonesia asli) dan WNA baik berstatus berkewarganegaraan tunggal maupun ganda. Kategori kedua sebanyak 4 (empat), termasuk pasutri yang menikah campur dengan batasan pada pasangan sesama WNI berstatus beda etnis dalam rumpun budaya di wilayah Indonesia (etnis Jawa dan etnis lain). Kategori ketiga sebanyak 3 (tiga), termasuk pasutri yang menikah campur dengan batasan pada pasangan sesama WNI berstatus beda keturunan orang asing atau luar etnis di wilayah Indonesia (etnis Indonesia asli dan keturunan asing).

Penelitian ini membatasi pada persoalan budaya dalam konteks umum, sehingga penelitian ini tidak terjebak pada problematika ideologi maupun dogma yang dianut secara individual, namun lebih pada kebebasan masing-masing mengutarakan pendapatnya. Dari 9 (sembilan) informan terdapat karakteristik masing-masing dalam membangun hubungan pasutri kawin campur. Berdasarkan usia masing-masing terdapat pada interval 31-58 tahun. Usia masa perkawinan 5-26 tahun. Pekerjaan 70\% melakukan kegiatan wirausaha tetap maupun sambilan meski ada pula yang berstatus karyawan. Semua bertemat tinggal dibangunan rumah milik sendiri. Kepemilikan anak hasil hubungan 0-4 orang. Latar belakang pendidikan Lulus Diploma sampai dengan Doktoral. Pernah melalukan perceraian (bukan mati) sebelumnya ada 0-3 pasangan.

\section{Pembahasan}

Pada pembahasan ini diuraikan mengenai berbagai hal yang berkaitan dengan fokus penelitian, dan utamanya menyangkut persoalan pada faktor-faktor 
yang dipandang penting dari dua sisi, baik oleh peneliti sendiri maupun informan penelitian yang terinci berikut ini.

\section{a. Penerapan Assertive Preference Values}

Assertive preference values dalam proses komunikasi memiliki makna yang berkaitan erat dengan dorongan batiniah, keberadaannya sangat dibutuhkan serta muncul sebagai dorongan psikologis untuk memberikan solusi terbaik. Hampir seluruh informan merasa tidak mengalami kendala, karena dapat mengkonstruksi cerita yang sedemikian rupa selama menjadi pasutri kawin campur. Ada pula yang mencontohkan mengenai perdebatan masalah selera makanan pasangannya, khususnya bersuamikan orang eropa yang sangat perhatian mengenai masakan. Begitu besar keinginan untuk menikmati masakan ala eropa yang dimasak oleh istrinya, maka dibuatlah masakan ala kadarnya yang menyerupai aslinya dengan menggunakan bahan baku lokal. Dari pengungkapan ini dapat dimaknai sebagai kecenderungan mengkonstruksi argumentasi antarbudaya, bahwa keterbatasan bukan lagi menumbuhkan konflik personal yang berkepanjangan, namun justru menumbuhkan nilai-nilai persahabatan dengan manajemen diri yang selalu dibangun bersama sebagai pujian menuju kesuksesan dalam rumah tangga.

Berdasarkan uraian tersebut di atas, maka seluruh informan menyadari assertive preference values dalam perilaku komunikasi pasutri. Bahkan pasutri kawin campur dapat memberikan rumusan secara garis besar sebagai berikut:
1) Mempertajam karakter pribadi.

Pentingnya memiliki kualitas interaksi yang tinggi, dengan demikian akan selalu terpelihara menentukan sikap, perilaku, kejujuran, etika dalam memberi perlakuan kepada pasangannya dengan dilandasi keterbukaan, empati, dan dukungan.

2) Memberi ruang proporsional.

Memperluas jangkauan dilandasi toleransi yang tinggi, dengan cara mengubah kendala berupa perbedaan menjadi tantangan manejemen diri dimulai dari perbedaan keyakinan, latar belakang ekonomi, posisi dalam profesi, dan kebebasan menentukan masa depan.

3) Mengembangkan skill bersama.

Menyusun alokasi waktu diantara kesibukan yang menyita waktu, dengan memberikan kesempatan yang luas pasangannya untuk menentukan faktorfaktor kesenangan personal maupun keluarganya, sehingga tercipta kesempatan untuk meningkatkan skill dalam membangun keluarga sesuai harapannya.

4) Menghargai setiap perbedaan.

Mempersempit jarak personal maupun sosial di lingkungannya, dengan menerima setiap kesenangan individu menjadi milik bersama melalui penghindaran terhadap konfrontasi yang memungkinkan konflik berkepanjangan.

5) Mempertegas dalam perilaku komunikasi.

Meningkatkan pemahaman pasangannya dengan sesering mungkin melakukan komunikasi dua arah secara berkesinambungan, agar selalu ada kesempatan yang luas untuk mengkonstruksi berbagai persoalan dalam suasana dialogis, sehingga dapat meminimalisasi 
problematika yang sebenarnya ringan menjadi semakin memberatkan hubungan pasutri.

Kondisi demikian banyak dialami oleh pasangan yang ada dalam kategori 1 maupun 3 dan sedikit sekali golongan 2, yaitu mengembangkan anggapan yang dilandasi stereotyping terhadap perkawinan campuran dengan orang asing atau keturunan asing. Alasan uang ataupun kekayaan selalu menjadi faktor yang dituduhkan, padahal banyak perkawinan campur sebenarnya mengalami kesulitan dalam tata kelola keuangan. Kadangkala pikiran dan pemahaman orang lain tersebut, dapat mengganggu hubungan pasutri kawin campur dengan lingkungan sekitarnya. Memberikan argumentasi atas dasar cinta, khususnya mengenai pasutri kawin campur kepada lingkungan sosial tidaklah semudah yang dibayangkan, sehingga keresahan inipun juga berdampak pada kondisi internal keluarga. Untuk itu masih diperlukan sikap positif, yaitu dengan cara menghargai latar belakang budaya pasangannya.

Bersandar pada uraian tersebut di atas, hakekatnya setiap pasutri kawin campur menyadari sepenuhnya fungsi keluarga yang dapat berperan ganda serta memberi kekuatan untuk mengembangkan ikatan personal yang dibutuhkan sebagai berikut:

1) Institusi keluarga merupakan tempat curahan yang dapat menampung berbagai perbedaan, dengan cara mengembangkan dialog secara berkesinambungan guna terbentuknya pola relasi yang berkualitas.

2) Kualitas dari relasi yang memenuhi harapan dapat dicapai dengan komitmen untuk mempertahankannya, selanjutnya diterapkan secara sungguh-sungguh sampai dengan mengatur hubungan dengan pihak lain di luar keluarga inti, seperti kepada keluarga besar berikut anggota-anggotanya.

3) Memperbanyak serta mempermudah informasi psikologis yang menggembirakan terkait dengan kebiasaan berperilaku, baik dalam memahami karakter pribadi maupun sikap bersama sebagai karakter slingkungan keluarga.

4) Heterogenitas yang terkait dengan faktor-faktor budaya, sedapat mungkin dijadikan alasan membangun toleransi dalam bentuk tindakan yang diperkaya melalui bentuk dialog terbuka demi tercapainya kesamaan cara pandang sebagai keluarga.

5) Inisiasi melakukan dialog sedapat mungkin menghindari problematika sensitif yang menyangkut perbedaan keyakinan serta tatacara menjalaninya, sehingga tidak menimbulkan tekanan psikologis yang tidak diharapkan bersama.

6) Mengembangkan sikap positif demi terjalinnya pasutri yang harmonis melalui kesungguhan meninggalkan prasangka buruk, meningkatkan frekuensi tersurat maupun tersirat yang dapat dimaknai sebagai saling menghargai, menghindari tumbuhnya jarak sosial dengan lebih mengutamakan kesetaraan, dan memberikan dukungan moral apabila salah satu mengalami hambatan dalam proses sosial.

7) Mempertunjukkan perilaku komunikasi yang menyenangkan pasangan maupun lingkungan sosialnya, agar semakin tinggi kualitas hubungan personal maupun sosialnya, dan secara langsung 
akan berdampak pula pada tingginya pemahaman mengenai arti pentingnya anggota keluarga dalam membina suatu hubungan.

8) Mempersempit ruang gerak keterlibatan pihak ketiga dalam hubungan keluarga inti dan keluarga besar, dengan cara meyakini problematika keluarga hanya bisa diselesaikan melalui kekuatan internal dalam bentuk ikatan personal.

\section{b. Inovasi Komunikasi Keluarga}

Konflik rumah tangga lebih cenderung mengarah pada perselisihan antara pihak-pihak dalam setiap interaksi nyata (manifest) maupun tersembunyi (latent). Persepsi menjadi alasan utama timbulnya konflik personal maupun sosial, dengan melibatkan tekanan psikologis berkesadaran yang dapat dimaknai menyerupai ekspresi. Kondisi seperti ini justru banyak dialami pasangan pada kategori 2 maupun 3 dan sedikit pada kategori 1, karena kesadaran melakukan tindakan relasi sebagai pasutri kawin campur mengalami kehilangan landasan utama dalam bentuk toleransi, sehingga mudah terbawa arus egois yang membentuk perilaku menjauhi harapan bersama. Sebagaimana diutarakan oleh informan yang berada dalam kategori 2 yang sedikit sekali terungkap dari kategori 1 dan 3, bahwa campur tangan pihak lain menjadi problem yang sulit teratasi jika melibatkan keluarga besar, karena konflik rawan terjadi apabila sudah menyentuh urusan pribadi diantara pasutri.

Meskipun dalam situasi yang berbeda, namun kondisi seperti ini juga ditemukan oleh (Dewi dan Basti, 2008), bahwa pada umumnya pasutri lebih mengedepankan tata kelola perasaan yang relatif santun. Bahkan untuk menghadapi setiap problematika selalu cenderung dilandasi pada luasnya pengalaman selama berkumpul, sehingga mudah muncul berbagai persoalan yang sebenarnya ringan namun menjadi gagasan yang dapat dikomunikasikan oleh keduanya. Kadangkala perselisihan muncul dengan semakin meninggi pada saat komunikasi berlangsung, dan sebaliknya akan terhenti setelah salah satu mengatur posisi untuk menghindari konflik. Penerimaan nilai-nilai budaya yang terbatas (limited acceptance) justru seringkali terjadi pada pasutri kategori 3 , meskipun kedua-duanya belum tentu berasal dari masyarakat lokal Malang. Munculnya kondisi ini terletak pada proses adaptasi yang tidak seimbang diantara pasutri, sehingga terjadi kesenjangan dalam menerapkan nilainilai kebersamaan yang diterima dan dijalankan. Kekurangsetujuan atas pemberlakuan nilai-nilai tersebut, sangat bergantung pada kelenturan menerima nilai-nilai sosial yang dianggapnya baru.

Hal ini seperti yang diidealkan dalam komunikasi keluarga dengan dilandasi orientasi pragmatis demi kepentingan banyak pihak dan orientasi logika konseptual. Pendekatan pragmatis merupakan upaya berkomunikasi untuk membangun hubungan harmoni, yaitu dengan menciptakan rasa senang yang dapat dinikmati secara bersama-sama. Sedangkan pendekatan logika lebih mengarahkan pada terciptanya iklim yang dapat memperkuat cara pandang secara bijak, yaitu dalam rangka mengatasi setiap masalah yang melanda keluarga. Keduanya saling memberi manfaat serta terjadi secara 
berkesinambungan, sehingga teridentifikasi berbagai cara berkomunikasi berikut ini.

1) Komunikasi keluarga dengan pola laissez-faire, ditandai dengan rendahnya komunikasi yang berorientasi konsep, artinya anak tidak diarahkan untuk mengembangkan diri secara mandiri, dan juga rendah dalam komunikasi yang berorientasi sosial. Artinya pasutri tidak membina keharmonisan hubungan dalam bentuk interaksi. Keluarga kurang atau tidak memahami objek komunikasi, sehingga dapat menimbulkan komunikasi yang salah.

2) Komunikasi keluarga dengan pola protektif, masih memandang terbatas tingkat kepentingannya untuk berkomunikasi dalam orientasi konsep, tetapi tinggi komunikasinya secara intensif kepada lingkungan sekitar. Keajegan serta dan keselarasan sangat dipentingkan dalam komunikasi dua arah. Pasutri yang berasal dari keluarga yang menggunakan pola protektif dalam berkomunikasi mudah dibujuk, karena tidak belajar membela atau mempertahankan pendapat sendiri.

3) Komunikasi keluarga pola pluralistik merupakan bentuk kelompok kecil seperti keluarga dengan menjalankan model komunikasi yang terbuka dalam membahas ide-ide yang melibatkan banyak pihak serta kepentingannya, dengan berkembang secara demokratis meskipun tetap mempertimbangkan kondisi personal seperti keterdukungan, atraktifitas, keterbukaan, dan sebagainya.

4) Komunikasi keluarga yang terarah menuju terciptanya konsensus, lebih memungkinkan semakin terbukanya asas demokratis yang mengedepankan musyawarah mufakat. Bentuk komunikasi keluarga ini menekankan komunikasi berorientasi sosial yang didukung oleh orientasi logika konseptual, sehingga setiap pihak yang terlibat merasa menjadi bagian dalam proses terciptanya norma-norma kekeluargaan, bahkan masing-masing memiliki kesempatan yang sangat luas untuk menyodorkan gagasan menurut perspektifnya sendiri dengan penuh percaya diri. (Sari, 2015).

Berdasarkan uraian tersebut di atas, maka seluruh informan menyadari pentingnya komunikasi keluarga untuk menghindari konflik personal maupun sosial. Pasutri kawin campur dapat merumuskan penyebab konflik serta cara menghindari maupun menyelesaikannya, demi tercipta keluarga yang sesuai dengan harapannya sebagai berikut:

1) Perbedaaan yang menyangkut nilai-nilai dari budaya asal menjadi pemicu tertinggi timbulnya konflik, mengingat hal ini sudah menjadi endapan dalam diri sejak lama, sehingga sulit diperbarui dengan keadaan yang saat sekarang sudah membentuk keluarga. Solusi yang dapat dipakai, adalah toleransi yang tinggi yang dilandasi kesadaran pebuh sebagai pasutri kawin campur serta membutuhkan penasehat.

2) Harapan dapat melakukan interaksi secara padat memang sulit bagi pasutri kawin campur yang rata-rata berwirausaha, kesempatan bisa berkumpul lebih panjang menjadi kebutuhan bersama. Namun tuntutan profesi serta keadaan ekonomi di dalam maupun di luar keluarga menjadi alasan paling mendasar. Solusi yang dapat digunakan, adalah memberikan ruang gerak bersama yang terjadwal secara 
ketat, sehingga peran masing-masing tidak terabaikan dalam struktur keluarga.

3) Ajaran agama dan kepercayaan yang menjadi panutan seolah-olah terlepas dari ikatan batiniah, sehingga perbedaan dalam membentuk keyakinan masih mendominasi keegoan masing-masing. Meskipun saling menyadari akan posisi masing-masing dalam perbedaan keyakinan, namun kenyataannya masih sering muncul dengan ditampakkan. Solusi yang digunakan oleh pasutri, adalah memperkuat keyakinan masingmasing dengan mempertebal nilai-nilai spiritual sepenuhnya kepada Tuhan.

4) Menghindari konflik sedini mungkin dengan memperkuat komunikasi, meyakini komunikasi tidak harus bersifat tatap muka, apalagi pada era modern dapat menggunakan media apapun bentuknya. Intensitas berkomunikasi dipastikan oleh pasutri sebagai solusi terbaik, karena segala sesuatunya dapat tercurahkan tepat pada waktunya.

5) Mencegah konflik dengan mengembangkan komunikasi dua arah timbal balik secara berkesinambungan, dengan mengutarakan ide-ide seputar kesenangan ataupun hobi masingmasing. Hal-hal lain yang dinilainya rawan seperti persoalan agama dan ekonomi, sedapat mungkin dibuang jauh serta berusaha untuk mencapai kesetaraan.

6) Bersama-sama membangun prinsip dasar dalam institusi keluarga, berdasarkan kesadaran untuk menghidupinya melalui komunikasi yang mampu memberi pendidikan serta pembentukan karakter seluruh anggota keluarga. Memperkenalkan fungsi masing-masing anggota keluarga, dan perannya dalam menciptakan keluarga yang harmonis.

\section{c. Perilaku Komunikasi Pasutri}

Perilaku komunikasi pada dasarnya menunjukkan, bahwa terdapat proses sadar yang dilakukan oleh semua pihak yang terlibat dalam interaksi untuk melakukan perilaku yang mengarah pada perubahan pemahaman menuju terwujudnya kebersamaan. Demikian pula pada pasutri kawin campur yang memiliki heterogenitas budaya, dapat melakukan kegiatan secara bersamasama dengan mempertimbangkan sikap egoisme, kesetaraan posisi dalam keluarga, sampai dengan penentuan nilai-nilai personal. Prioritas dalam membangun komunikasi keluarga, pada dasarnya mengembangkan sikap yang dilandasi nilai-nilai positif terhadap pasangannya maupun anggota keluarganya. Faktor-faktor yang menonjol justru terletak pada perilaku komunikasi yang disadarinya berdampak terhadap keharmonisan dalam keluarga seperti memotivasi pasangannya dalam bahasa yang mudah dipahami, mengutamakan keterbukaan dengan lingkungan internal dan eksternal, memperkuat empati dengan memahami perasaan pasangannya, dan secara keseluruhan diwujudkan melalui prinsip perbedaan merupakan sesuatu untuk saling melengkapi (DeVito, 2015).

Prinsip dalam membangun komunikasi justru berkembang secara signifikan diantara seluruh informan, meskipun sebagian kecil terutama pada kategori 3 menganggap masih terdapat kendala dalam bentuk kesalahpahaman dalam proses komunikasi. Penggunaan bahasa yang diselingi istilah lokal (Jawa 
atau daerah lain), kadangkala menjadi persoalan kecil yang sering muncul ke permukaan. Sedangkan informan lain, mengalami kendala dalam persoalan keterbukaan yang membutuhkan proses penyesuaian cukup lama, khususnya pada pasangan yang mengutamakan keterjagaan nilai-nilai pribadi. Disamping itu juga masih terdapat sikap apriori terhadap budaya lokal Jawa, mengingat kebiasaan pasangannya lebih mengutamakan keterusterangan yang seyogyanya ditunjukkan. Meskipun demikan pada akhirnya pasutri mampu menikmati keterbukaan dalam membangun hubungan dengan lingkungannya. Informan dari kategori 2, masih belum mampu sepenuhnya dalam memahami pasangan sebagai sesama profesional wirausaha, meskipun komunikasi secara sarat makna dilakukan setiap saat ada kesempatan. Hal ini sejalan dengan hasil studi yang dilakukan oleh Salaky (2014), bahwa pentingnya kemampuan psikologis memberi peluang tumbuhnya umpan balik yang diarahkan untuk menjaga keselarasan komunikasi interpersonal pasutri. Proses ini memungkinkan terjadinya komunikasi yang efektif hingga berdampak pada baiknya hubungan.

Mayoritas informan mengungkapkan, bahwa konflik yang sering terjadi dengan gambaran tersebut di atas, bukanlah sesuatu yang membuatnya semakin terpuruk dengan keadaan. Hampir semua menganggap selama masih mampu melakukan komunikasi, maka segala persoalan dapat teratasi tepat pada saatnya. Konflik baginya hanya sebuah motif paling mendasar untuk membangun komunikasi yang lebih baik, dan menganggapnya sebagai perangsang kecerdasan dalam mempererat hubungan persahabatan. Bahkan secara sadar informan mampu merumuskan berbagai faktor untuk membangun komunikasi yang efektif, yaitu dengan usaha sedapat mungkin menemukan solusi terbaik atas konflik yang timbul sebagai berikut:

1) Meningkatkan kecerdasan berkomunikasi dengan mendengarkan secara efektif setiap gagasan pasangannya serta bersedia memberikan feedback yang positif.

2) Komunikasi selalu diusahakan untuk memasuki pola pikir pasangan, sehingga dapat memahami persepsi dan berbagai opini yang muncul pada saat terjadinya konflik.

3) Menghindari munculnya gagasan komunikasi untuk saling menyalahkan, yaitu dengan mengembangkan manajemen diri melalui high context communication yang penerapannya secara tersamar.

4) Mengubur sedalam mungkin pesanpesan yang mengungkap catatan buruk masa lalu, yaitu dengan cara mempersempit ruang inisiasi yang dapat memperlebar masalah.

5) Menghindari sedapat mungkin bersikap defensif dalam berkomunikasi, dan selalu mengakomodasi pendapat pasangannya dalam perilaku komunikasi verbal.

6) Komunikasi mendukung proses mengenal lebih jauh budaya pasangannya, agar dapat memetik faktor-faktor yang dinilainya masih rendah, dan setiap keunggulannya dijadikan kesempatan untuk menikmati sebagai faktor yang menyenangkan pasangannya. 
7) Komunikasi bersifat manasea sebagai yang bukan satu-satunya faktor dalam menyelesaikan konflik. Namun dengan mengembangkan komunikasi dialogis, akan dapat menjamin lebih memahami pasangannya dalam mencapai kebersamaan dengan melibatkan emosi, ekspresi, dan kedekatan intim.

\section{d. Penerapan Drama Turgi Keluarga}

Disadari atau tidak dalam kehidupan dan proses interaksinya sehari-hari, banyak individu yang melakukan pengelolaan kesan, khususnya jika individu tersebut menjalani suatu profesi atau tugas tertentu yang bersinggungan dengan masyarakat. Demikian juga untuk keluarga kecil yang berbeda budaya. Informasi yang didapatkan dan diolahnya, semata-mata untuk dapat membangun kedekatan dengan keluarganya. Tampilan diri inilah yang disebut sebagai dramaturgi. Gagasan Erving Goffman dengan cara pandang ini memberikan arah, bahwa kehidupan pasutri yang berlainan budaya tidak jauh berbeda dengan pasutri lainnya, selalu dapat ditinjau sebagai pertunjukkan panggung yang mengedepankan upaya setiap individu menjadi pemeran terbaik dalam sebuah cerita keluarga. Penataan cara berkomunikasi, berpakaian dimaksudkan untuk meningkatkan kesan mempresentasikan dirinya dengan baik, untuk menunjukkan keberhasilan dalam menjalankan fungsi pada hubungan pasutri.

Mengadopsi hasil studi Febriani (2016) telah memberikan pemahaman, bahwa adakalanya salah satu pasutri masuk ke dalam kehidupan pasangannya maupun keluarga besarnya. Hal inilah yang memposisikan setiap pasangan berusaha memenuhi hasratnya untuk dipandang menjadi insan yang terbaik dalam gambaran utuh keluarga. Simbol-simbol bermakna yang ditransformasikan semakin memberikan warna tersendiri atau menjadi identitas yang mudah untuk dikenali sebagai karakter pribadi untuk diterima lingkungan keluarga besar pasangannya. Ada kalanya problematika yang dikembangkan telah usai, maka akan mudah dikenali karakater individu masing-masing yang bisa jadi berbeda dengan tampilan sebelumnya. Untuk hal ini Goffman mengasumsikan, bahwa ketika pasutri dan lingkungannya berinteraksi, dipastikan dapat ditemukan keasian karakter diri yang telah dipersepsikan pihak lain. Tampilan diri atau lebih dikenal dengan personality performance merupakan penerapan pada lingkup terbatas yang disebut dengan an acting of the self image (keharusan melakukan tindakan tertentu sebagai upaya memperoleh citra diri yang positif dalam keadaan apapun).

Pasutri beda budaya yang dapat disebut sebagai aktor harus memusatkan pikiran, agar tidak mengalami kondisi sangat fatal dalam proses komunikasi, menjaga kendali diri melakukan gerakgerik, menjaga nada suara dan mengekspresikan wajah sesuai dengan situasi yang berkembang pada lingkup keluarga, keluarga besar, dan lingkungan sosial yang lebih luas. Demikian pula komunikasi keluarga, bahwa individu dalam berkomunikasi baik secara verbal maupun non-verbal akan selalu membawa dampak perubahan secara resiprositas. Aktor harus memusatkan pikiran, agar dia 
tidak keseleo lidah, menjaga kendali diri melakukan gerak-gerik, menjaga nada suara dan mengekspresikan wajah sesuai konteks komunikasinya. Inilah yang disebut dengan self performance yang semakin dipahami sebagai produksi makna, yaitu kemampuan masing-masing individu di lingkungan terbatas yang memperlihatkan identitas diri sebagai identitas sosial bawaan, sehingga setiap proses komunikasi selalu saja berpengaruh pada proses interaksi nilai-nilai yang dimunculkan maupun norma-norma yang diperbandingkan dalam berbagai situasi (Mulyana, 2003: 112).

Presentasi diri tidak hanya terjadi ketika berusaha untuk mengesankan orang tetapi juga ketika berusaha untuk menampilkan diri dengan cara yang mengungkapkan cita- cita batin dan membangun reputasi yang sesuai. Dalam proses ini persepsi sangat berperan besar untuk memberikan penilaian, khususnya mengenai presentasi diri seseorang mengenai upaya untuk mengkonstruksi setiap tingkah laku yang dimunculkan oleh pasutri selaku pemeran utama dalam drama keluarga. Elemen diri yang disebut dengan hasrat memiliki posisi sentral dalam merangsang persepsi dalam bentuk identitas diri, juga proses atribusi semakin mempercepat produksi makan terhadap diri seseorang. Disinilah dapat diintrodusir mengenai proses psikologis dalam manajemen komunikasi yang melibatkan konsep diri, bahwa penampilan diri hanya bisa dimaknai dari upaya seseorang dalam memposisikan dirinya diantara orang lain pada saat itu. Demikian pula posisi pasutri yang menjadi aktor dalam drama keluarga, akan melalukan upaya akumulatif diantara karakter pribadi dan tujuannya melakukan tindakan tertentu melalui proses dramatisasi, dan cara memposisikan alam sekitarnya sebagai pendukung memproduksi makna (Febriani, 2016).

Setiap pasutri dalam membangun keluarga yang diharapkan membawa misi memperoleh kebahagiaan. Terbebas dari segala macam bentuk tekanan diri maupun sosial yang melanda rumah tangganya. Berharap besar untuk dipandang sebagai keluarga yang rukun penuh kedamaian, merupakan upaya yang selalu diperjuangkan dihadapan orang lain maupun masyarakat sekitarnya. Untuk itulah menjadi sangat bisa dipahami, apabila penampilan diri yang bersifat statis atau menetap dapat menjadi identitas bagi keluarganya, sedangkan tampilan diri yang bersifat dinamis merupakan identitas sosial yang dapat menerima keberagaman. Presentation of Self menjadi berlaku pada saat pasutri memainkan perannya dihdapan pihak lain yang membutuhkan perhatiannya. Disinilah panggung drama keluarga semakin mendapatkan posisi paling menentukan untuk memelihara keharmonisan maupun mengelola konflik yang selalu ada. Bahkan pendukung dramaturgisme memberikan cara pandang yang sangat tepat untuk memandu pementasan keluarga beda budaya. Dapat dikenal adanya front stage yang mempersiapkan tata kelola panggung, dan pembawa cerita atau pemeran utama maupun pendukung yang dengan leluasa menyampaikan gagasan-gagasan. Pada back stage lebih menekankan adanya persiapanpersiapan yang harus dijalankan secara detail (impression management), 
menentukan tata cara penyampian informasi atau gagasan semenarik mungkin (mystification), yaitu dengan berusaha mengubur dalam-dalam segala sesuatu yang dipandang buruk oleh pasutri maupun keluarga besarnya (Fitri, 2015).

Dengan demikian pasutri melakukan pementasan teater dengan berbagai jenis peran yang biasa dimainkan seseorang dalam interaksi dan komunikasi sehari-hari. Pasutri melakukan pengelolaan kesan dalam kegiatan berdekatan dengan pasangannya, anak-anaknya, keluarga besarnya maupun lingkungan sosialnya ketika berinteraksi dan berkomunikasi. Pendekatan dramaturgi Erving Goffman berintikan persepsi yang dikonstruksikan melalui penampilan diri secara interaktif, memberikan batasanbatasan dalam mengatur munculnya persepsi agar terkendali dengan baik, sehingga semua dapat berjalan secara normal dan alami dalam proses pertunjukkan drama keluarga. Kajian dramaturgi menganggap kehidupan diibaratkan sebagai pertunjukan drama, dimana individu merupakan aktor dalam kehidupan. Kajian dramaturgi berintikan bahwa setiap aktor berperilaku bergantung pada peran sosialnya dalam situasi tertentu (Siregar, 2016).

\section{PENUTUP}

\section{Simpulan dan Saran}

Upaya pasutri yang berbeda budaya dalam tindakan mengkonstruksi assertive preference values pada perilaku komunikasinya, hanya dapat dilakukan apabila mampu memainkan perannya secara komprehensif, yaitu satu sisi bertindak sebagai pasangan, sisi lain bertindak bertindak sebagai bagian dari keluarga, dan juga sebagai bagian dari lingkungan sosialnya. Hal inilah yang disebut dengan pembagian peran tampak depan (front stage) yang dikendalikan oleh suasana batiniah yang disebut dengan kendali belakang (back stage), sehingga mudah membiasakan untuk selalu mengungkapkan nilai-nilai yang menjadi kesenangan bagi pasutri, selanjutnya dinormakan menjadi sikap yang dapat ditingkatkan serta dipelihara bersama. Pembudayaan ini memang tidak mudah serta cenderung bersifat kompleksitas, bahkan membutuhkan pembiasaan yang dapat diterima sebagai adat istiadat bersifat konvensional. Maraknya gugatan perceraian dan tingginya kasus perceriaan yang sulit dirujukkan kembali, akan semakin muah teratasi dengan mengedepankan prinsip-prinsip mengatasi persoalan tanpa adanya upaya pemaksaan, bagaimanapun keluarga adalah institusi penting yang dapat dimiliki setiap orang, walaupun upaya untuk mempertahankannya membutuhkan enerji kesadaran tinggi. Assertive preference values memang atetap harus diunggulkan, namun menjadi semakin bermakna posisinya dalam instritusi keluarga, apabila didukung oleh keseimbangan peran strategis (a strategy of the drama turgi concept).

\section{DAFTAR PUSTAKA}

Abas, F., Laisa, Z., dan Talani, N.S. (2014). Pernikahan Dua Etnis Berbeda Dalam Perspektif Komunikasi AntarBudaya. http://kim.ung.ac.id/index.php/KIMF IS/article/ download/ 8180/8069. 
Biro Pusat Statistik Kota Malang. (2017). Laman ditampilkan pada tanggal 20 Maret $2017 \quad 09: 09: 15$ http://malangkota.go.id/tag/bps-kotamalang/.

Bungin, B. (2001). Metode Penelitian Kualitatif. Jakarta: Raja Grafindo Persada.

DeVito, J.A. (2015). Komunikasi Antarmanusia. Tangerang Selatan: Kharisma Publishing Group.

Dewi, Eva Meizara Puspita, Basti (2008). Konflik Perkawinan dan Model Penyelesaian Konflik Pada Pasangan Suami Istri. http://ejournal.gunadarma.ac.id/index .php/ psiko/article/view File /243/184.

Febriani, Elvia. (2016). Presentasi Diri Seorang Intel Di Sat Intelkam Polres Kabupaten Rokan Hilir (Rohil) Dalam Pengungkapan Kasus Pencurian. JOM FISIP Vol. 3 No. 1 Februari 2016. https://jom.unri.ac.id/index.php/JOM FSIP/article/view/8137

Fitri, Ainal. (2015. Drama Turgi: Pencitraan Prabowo Subianto Di Media Sosial Twitter Menjelang Pemilihan Presiden 2014. JURNAL INTERAKSI, Vol. 4 No. 1, Januari 2015.

http://ejournal.undip.ac.id/index.php/ interaksi/article/download/9740/7808

Hudiyanto, R. Reza. (2011). Menciptakan Masyarakat Kota. Yogyakarta: Lilin.

Hutajulu, L.V. (2015). Strategi Komunikasi Efektif Suami-Istri Beda Budaya Dalam Mendidik Anak: http://jurnal.usu.ac.id/index.php/flow /article/download/11560/4965

Karel, R.S., Sondakh, M., dan Pasoreh, Y. (2014). Komunikasi Antar Pribadi
Pada Pasangan Suami Istri Beda Negara. Acta Diurna Volume III. No.4 2014: http://ejournal.unsrat. ac.id/

index.php/actadiurna/article/viewFile 15854/5387.

Littlejohn, S.W., Karen A.F. (2009). Teori Komunikasi. Jakarta: Salemba Humanika.

Mulyana, Deddy. (2009). Metode Penelitian Kualitatif. Bandung: Remaja Rosdakarya.

Oktafiani, N.L., Ramli, A.H., dan Kurniawati, Y. (2014). Manajemen Konflik Pada Pasangan Suami Istri Yang Menjalani Perkawinan Campuran. http://www.e-jurnal.com/ 2015/09/manajemen-konflik-padapasangan-suami.html.

Salaky, S. (2014). Pola Komunikasi Interpersonal Dalam Perspektif Psikologi-Komunikasi Pada Pasangan Suami Istri Beretnis JawaAmbon. Populis Volume 8 No. 1 Maret 2014. http:// ejournal.unpatti.ac.id/ppr_iteminfo_1 nk.php?id.

Sari, Afrina. (2015). Model Komunikasi Keluarga Pada Orang Tua Tunggal (Single Parent) Dalam Pengasuhan Anak Balita. Jurnal Ilmu Komunikasi Vo.3 No.2. Desember 2015.

Siregar, Hari Indrawan. (2016). Pendekatan Drama Turgi Dalam Komunikasi Guru Bimbingan Konseling Di SMPN 1 Batangkuis. http://www.e-jurnal.com/2016/ 05/pendekatan-teori-dramaturgidalam.html.

Sugiyono (2015). Metode Penelitian Kuantitatif, Kualitatif dan $R \& D$. Bandung: Penerbit Alfabeta. 